\title{
Infectious necrotizing enteritis and mortality caused by Vibrio carchariae in summer flounder Paralichthys dentatus during intensive culture*
}

\author{
Bruno Soffientino ${ }^{1}$, Todd Gwaltney ${ }^{2}$, David R. Nelson ${ }^{2}$, Jennifer L. Specker ${ }^{1}$, \\ Michael Mauel ${ }^{3}$, Marta Gómez-Chiarri ${ }^{4, * *}$
}

\footnotetext{
${ }^{1}$ University of Rhode Island, Graduate School of Oceanography, South Ferry Rd, Narragansett, Rhode Island 02882-1197, USA

${ }^{2}$ Department of Biochemistry, Microbiology, and Molecular Genetics, ${ }^{3}$ Laboratory of Vector Borne Diseases, and

${ }^{4}$ Department of Fisheries, Animal and Veterinary Science, University of Rhode Island, Kingston, Rhode Island 02881, USA
}

\begin{abstract}
An epizootic causing mortality among cultured summer flounder Paralichthys dentatus occurred in summer of 1998 at a land-based facility on Narragansett Bay, Rhode Island, USA. The disease, flounder infectious necrotizing enteritis (FINE), was characterized by reddening around the anal area, distended abdomens filled with opaque serosanguineous fluid, enteritis and necrosis of the posterior intestine. In extreme cases of the disease, the posterior intestine was detached from the anus and was observed coming out the vent. The intestine of individuals that recovered from the disease ended in a blind-sac; the abdomens of these fish were distended, due to food and water inside the intestinal blind-sac. A bacterium was isolated from ascites fluid and kidney of moribund flounder and identified as the causative agent in challenge experiments. The pathogen was identified as Vibrio carchariae by morphological and biochemical characteristics and sequence of the $16 \mathrm{~S}$ rRNA. The $\mathrm{LD}_{50}$ estimate was $5 \times 10^{5}$ colony-forming units injected intraperitoneally into 100 to $200 \mathrm{~g}$ summer flounder.
\end{abstract}

KEY WORDS: Flounder infectious necrotizing enteritis (FINE) - Vibriosis - Enteritis · Paralichthys dentatus · Vibrio carchariae A Aquaculture

\section{INTRODUCTION}

The summer flounder Paralichthys dentatus is a commercially and recreationally important species of flatfish found in coastal waters of the eastern United States. These fish spawn on the continental shelf in the winter and are transported as larvae to the coastal and estuarine areas in the spring where they complete metamorphosis (Burke et al. 1991, Keefe \& Able 1993). The population of this species, through a combination of factors, has declined to the point that restrictions on the catch have been implemented (NOAA/NMFS 1993). This situation has led to an interest in the culture of summer flounder, with effort being invested in the development of both land-based and nearshore culture systems on the East Coast of the United States.

- All authors contributed equally to the authorship of this article

- Addressee for correspondence. E-mail: gomezchi@uri.edu
Commercial production of summer flounder began in 1996, stimulated by research performed at the University of Rhode Island (URI) and the success of flatfish culture in Europe and Japan (Bengtson 1999). In view of what has happened in similar enterprises, it was expected that the development of intensive culture of summer flounder would be constrained by infectious diseases. Flatfish culture facilities worldwide have reported disease problems and mortalities associated with bacterial, viral and parasitic pathogens (see chapters in Stoskopf 1993). Proliferative dermatitis in cultured larvae and juvenile Japanese flounder Paralichthys olivaceous was caused by Herpesvirus scophthalmi (Iida et al. 1989). Nodavirus causing viral nervous necrosis was described as the cause of high mortality in cultured Japanese flounder larvae (Nguyen et al. 1994). An atypical strain of Aeromonas salmonicida has been associated with ulcerative skin disease in wild-caught and cultured adult flounder (Wiklund 
\& Dalsgaard 1998). Different species of Vibrio have caused disease and mortality in wild winter flounder Pleuronectes americanus (Levin et al. 1972), cultured turbot Scophthalmus maximus (Lupiani et al. 1989, Grisez et al. 1996) and cultured Japanese flounder larvae (Ishimaru et al. 1996).

In this report, the first occurrence of an epizootic disease of cultured summer flounder, which happened during the summer 1998 at a grow-out facility located on Narragansett Bay, Rhode Island (USA), is described. The causative agent of this disease, flounder infectious necrotizing enteritis (FINE), is identified as Vibrio carchariae and the gross and histopathological signs of this infection described. During this event, 6 mo old summer flounder suffered approximately $30 \%$ mortality, and the connection between the anterior intestine and the anus was missing in about $15 \%$ of the survivors, with the intestine ending in a blind-sac. Although the survivors with this abnormality continued to feed, their growth was stunted when compared to siblings with normal intestines.

\section{MATERIALS AND METHODS}

Quonset Point Commercial Flounder Facility. Juvenile summer flounder ( 3 to $5 \mathrm{~g}, 6 \mathrm{mo}$ old) were transported from New Hampshire (Great Bay Aquafarms, Inc.) to Quonset Point, Rhode Island (VG Seafarms, LCC) on June $15(n=7300)$, June 23 ( $n=6475)$, and July $7(n=8000)$. The 3 groups of fish were held in separate shallow raceways $(17 \mathrm{~m} \times 1.8 \mathrm{~m} \times 6-8 \mathrm{~cm})$ and fed manually to satiation several times daily (Corey, New Brunswick; Zeigler Bros., Pennsylvania). The water was recirculated salt water, UV sterilized at the inflow (solid state, $390 \mathrm{~W}, 6 \times 60^{\prime \prime} \mathrm{T} 20$ bulbs). Mortality, salinity, and water temperature in each raceway were recorded daily. Salinity ranged from 21 to $28 \mathrm{ppt}$, and temperature was between 21 and $24^{\circ} \mathrm{C}$ (see Fig. 1). Water quality was determined occasionally: $\mathrm{pH}$ ranged between 7.2 and 7.7 , dissolved oxygen between 4.2 and $9.9 \mathrm{mg} \mathrm{l}^{-1}$, and ammonia was detected only once $\left(0.2 \mathrm{mg} \mathrm{i}^{-1}\right)$.

University of Rhode Island Research Flounder Facility. Healthy juvenile summer flounder used in the challenge experiments were provided by URI's Flounder Facility at Narragansett Bay Campus (Bengtson 1999). Juveniles were reared in flow-through seawater at ambient temperature (summer months, temperatures ranging from 16 to $21^{\circ} \mathrm{C}$ ). Salinity ranged from 26 to $30 \mathrm{ppt}$, $\mathrm{pH}$ ranged between 7.9 and 8.2 and ammonia was below $1 \mathrm{mg} \mathrm{l}^{-1}$.

Pathology. The description of gross and histological lesions is based on examination of 6 fish (100 to $200 \mathrm{~g}$ ) collected at the Quonset Point Facility during the initial outbreak that showed clear signs of disease (distended abdomens, red anus). Flounder were anaesthetized in 2-phenoxyethanol $(0.2 \% \mathrm{v} / \mathrm{v}$, Sigma) and the spine was severed at the base of the head using a scalpel. Ascites fluid was collected for challenge experiments and bacterial culture. Tissues, including gills, heart, brain, liver, kidney, spleen and anterior and posterior intestine, were fixed in 10\% neutral-buffered formalin and processed for paraffin embedding, sectioned, and stained with haematoxylin and eosin. Tissue samples from flounder challenged with the agent were similarly processed. In order to determine the status of the survivors from the outbreak at Quonset Point, 54 fish were netted from the raceways at the grow-out facility on October 1, 1998. Body weight and standard length (from tip of snout to terminal vertebrae) were recorded. The fish were dissected to determine the status of their gastrointestinal tract by visual examination.

Challenge experiments. In order to determine the nature of the pathogen, fish ( $\mathrm{n}=6$ per experimental group) were injected with $0.5 \mathrm{ml}$ Nine Salts Solution (NSS, Marden et al. 1985) (control group), $0.5 \mathrm{ml}$ ascites fluid collected from moribund fish (Group 1), or $0.5 \mathrm{ml}$ ascites fluid filtered through a $0.22 \mu \mathrm{m}$ Millipore filter (Group 2). All challenge experiments were performed using flounder (100 to $200 \mathrm{~g}$ ) from the URI Flounder Facility. For a given experiment, fish were netted out of the common tank, anesthetized with 2 phenoxyethanol, injected intraperitoneally (i.p.) with the appropriate preparation of bacteria in NSS and immediately transferred to the holding tank. Control groups, run in all challenges, were injected with NSS without bacteria. Following injection, fish for each experimental group were kept in separate $80 \mathrm{l}$ tanks (5 to 6 fish $\operatorname{tank}^{-1}$ ) containing seawater at room temperature (approximately $24^{\circ} \mathrm{C}$ ) with strong aeration. The water was changed 3 times a week for the duration of the challenges, which in all cases lasted at least 2 wk. Fish were not fed during the experiments and dead fish were removed twice daily. Mortalities were recorded and samples from different tissues of recently dead fish were collected aseptically for histopathology and isolation of bacteria.

In order to determine which bacterial isolate was responsible for mortality, 5 bacterial isolates (1-5) showing different colony morphologies were selected from moribund fish ascites fluid which had been streaked onto blood agar (Tryptic soy agar with 5\% sheep blood, PML Microbiologicals, Mississauga, ONT, Canada) and Luria-Bertani broth $+2 \% \mathrm{NaCl}$ (LB20, Nelson et al. 1997) plates. The isolates were selected because of their presence in the kidney and all ascites fluid samples from diseased fish. Each of the isolates was injected into fish ( $\mathrm{n}=5$ isolate $^{-1}$ ) at a dose of $1 \times$ $10^{6}$ cells in $0.1 \mathrm{ml}$ NSS. Each group of fish injected with 
a given isolate was maintained in a separate 801 tank. The fish were monitored daily for signs of disease. Ascites fluid and kidney tissue were obtained from moribund fish and streaked onto blood agar plates to determine whether the particular isolate injected into the fish could be re-isolated. All pure culture isolates were grown to stationary phase in LB20 plates and stored in $10 \%$ glycerol at $-75^{\circ} \mathrm{C}$.

Microbiology and biochemical tests. Bacteria were routinely grown in LB20 or on LB20 agar plates at $28^{\circ} \mathrm{C}$. Cells were also grown on blood agar plates, thiosulfate-citrate-bile salt agar (TCBS) plates, McConkey agar plates, or in marine minimal medium (3M, Neidhardt et al. 1974 ) at $28^{\circ} \mathrm{C}$. For some experiments, cells were grown overnight in LB20 with shaking to stationary phase, pelleted by centrifugation $(10000 \times \mathrm{g}, 10 \mathrm{~min}$, at $4^{\circ} \mathrm{C}$ ), washed twice in NSS, and resuspended in volumes of NSS to give specific concentrations of cells. Bacterial cell concentration was determined by serial dilution and plating on LB20 agar plates. All plate counts were performed in triplicate.

Sensitivity to $\mathrm{O} / 129\left(20 \mu \mathrm{g}\right.$ disk $\left.^{-1}\right)$, ampicillin $(100 \mu \mathrm{g}$ $\left.\mathrm{ml}^{-1}\right)$ and tetracycline $\left(10 \mu \mathrm{g} \mathrm{ml}^{-1}\right)$ was determined by incubating the bacteria in LB20 containing either of the antibiotics. The lack of growth indicated sensitivity. The biochemical tests used to identify the pathogen included the API 20E test kit (BioMérieux Vitek, Inc., Hazelwood, MO, USA) plus catalase and nitrate tests. Inocula for the biochemical tests were prepared by streaking an isolate on LB20 agar plates and picking individual colonies from the plate, suspending each colony in $5 \mathrm{ml} \mathrm{NSS}$, and using the cell suspension to inoculate each test strip. Strips were incubated at $28^{\circ} \mathrm{C}$ for at least $48 \mathrm{~h}$. All tests were performed and read according to the instructions of the manufacturer. The effect of $\mathrm{NaCl}$ concentration on bacterial growth was tested by inoculation of a $10 \mu \mathrm{l}$ sample from an overnight culture into tubes containing $10 \mathrm{ml}$ of LB medium with different amounts of $\mathrm{NaCl}$ (from 0 to $10 \%$ $\mathrm{NaCl}$. Tubes were incubated at $28^{\circ} \mathrm{C}$ for up to $5 \mathrm{~d}$. The effect of temperature on bacterial growth was evaluated by inoculation of a $10 \mu \mathrm{l}$ sample from an overnight culture into tubes containing LB20. Tubes were incubated at different temperatures (from 4 to $42^{\circ} \mathrm{C}$ ) for up to $72 \mathrm{~h}$.

Virulence estimation. The $\mathrm{LD}_{50}$ for the pathogen was determined by injecting 4 groups of fish $(n=5)$ with either $10^{4}, 10^{5}, 10^{6}$, or $10^{7}$ bacterial cells in $0.1 \mathrm{ml}$ NSS and following the same experimental protocol used in the challenge experiments. The results from duplicate experiments were pooled and subjected to probit analysis (PROC LOGISTIC, SAS Institute Inc. 1996, Version 6.12, Cary, NC, USA).

DNA sequence determination and analysis. Genomic DNA was isolated from a bacterial colony of Iso- late 2 from a fresh plate using DNA-Stat 60 (Tel-Tex Inc., Friendwood, TX, USA) according to the manufacturer's protocol. To amplify the $16 \mathrm{~S}$ rDNA gene, $10 \mu \mathrm{l}$ of DNA was added to $90 \mu$ l of reaction mixture consisting of PCR buffer (Biolase, ISC BioExpress, Kaysville, UT, USA), 200 mmol each of dATP, dCTP, dTTP, dGTP, 1 umol universal bacterial primer 27F (Lane 1991), 1 mmol universal bacterial primer 1518R (Lane 1991), and 2.5 Units Biolase DNA polymerase (ISC BioExpress). The mixture was denatured at $94^{\circ} \mathrm{C}$ for $2 \mathrm{~min}$ and amplification was achieved with 35 cycles of $94^{\circ} \mathrm{C}$ for $1 \mathrm{~min}, 50^{\circ} \mathrm{C}$ for $2 \mathrm{~min}$, and $72^{\circ} \mathrm{C}$ for $3 \mathrm{~min}$. The amplification was followed by an extension period of $72^{\circ} \mathrm{C}$ for $7 \mathrm{~min}$ and the reaction then held at $4^{\circ} \mathrm{C}$.

An aliquot $(10 \mu \mathrm{l})$ of the $\mathrm{PCR}$ reaction mixture was fractionated in a $1.5 \%$ agarose $1 \times$ TAE pH $8.0(40 \mathrm{mM}$ Tris acetate, $1 \mathrm{mM}$ EDTA) gel containing $0.2 \mu \mathrm{g} \mathrm{ml}^{-1}$ ethidium bromide and photographed under UV transillumination to confirm amplification of the correct size and purity. The PCR product was purified using the PCRquick Kit (Qiagen, Valencia, CA, USA) according to the manufacturer's instructions. Sequencing was carried out by the Central Services Laboratory (Oregon State University, Corvallis, OR, USA) on an ABI 377 automated sequencer (Perkin Elmer, Applied Biosystems Inc., Foster City, CA, USA) using the universal sequencing $16 \mathrm{~S}$ primers: $27 \mathrm{~F}, 1518 \mathrm{R}, 519 \mathrm{~F}$, 519R, 1100F, 1100R, 1406F, 1406R (Giovannoni 1990, Lane 1991) and dye-terminator kits supplied by Applied Biosystems Inc. The sequence determined in this investigation has been deposited in the GenBank nucleotide database and given accession number AF134581. The following bacterial sequences were obtained from the GenBank and EMBL databases and used in the construction of phylogenic trees: Aeromonas salmonicida $\times 74680$, Plesiomonas shigelloides X74688, Vibrio alginolyticus X74690, Vibrio anguillarum X16895, Vibrio carchariae X74693, Vibrio cholerae serovar O1 X74694, Vibrio cholerae Eltor X74695, Vibrio costicola X74699, Vibrio fisheri X74702, Vibrio furnisii X74704, Vibrio harveyi X74706, Vibrio hollisae X74707, Vibrio logei X74708, Vibrio metschnikovii $\mathrm{X} 74711$, Vibrio natriegens $\mathrm{X74714}$, Vibrio nereis $\mathrm{X}$ 74716, Vibrio ordalii $\times 74718$, Vibrio orientalis $X 74719$, Vibrio parahaemolyticus X74721, and Vibrio vulnificus X76333 (Ruimy et al. 1994). Sequences were aligned using the Clustal program (Higgins et al. 1991) followed by manual alignment. Phylogenetic relationships were determined using parsimony with the program PAUP version 3.1.1 (D. L. Swofford 1993; PAUP: phylogenic analysis using parsimony; Illinois Natural History Survey, Champaign, IL) using the general heuristic search option followed by bootstrap analysis (100 replications). 


\section{RESULTS}

\section{Mortality at the grow-out facility}

High levels of mortality were observed in the 3 raceways of the VG Seafarms facility 1 wk after arrival of the fish from the hatchery (Fig. 1a). Diseased fish stopped feeding and stayed at the end of the raceway, while healthy fish stayed next to the incoming water flow. In the $6 \mathrm{wk}$ period from mid-July to the end of August cumulative mortality rates of 32,35 , and $40 \%$ were suffered by the 3 groups of fish (in order of arrival). During this period, water temperatures tended to exceed $21^{\circ} \mathrm{C}$ (Fig. 1b).

\section{Pathology of FINE}

Gross signs included distended abdomens, reddening around the anal area (Fig. 2a) and occasionally reddening of the skin in the ventral area. Distended abdomens were filled with a serous milky and/or reddish fluid, containing bacteria and blood cells. In extreme cases of the disease, the intestine was detached

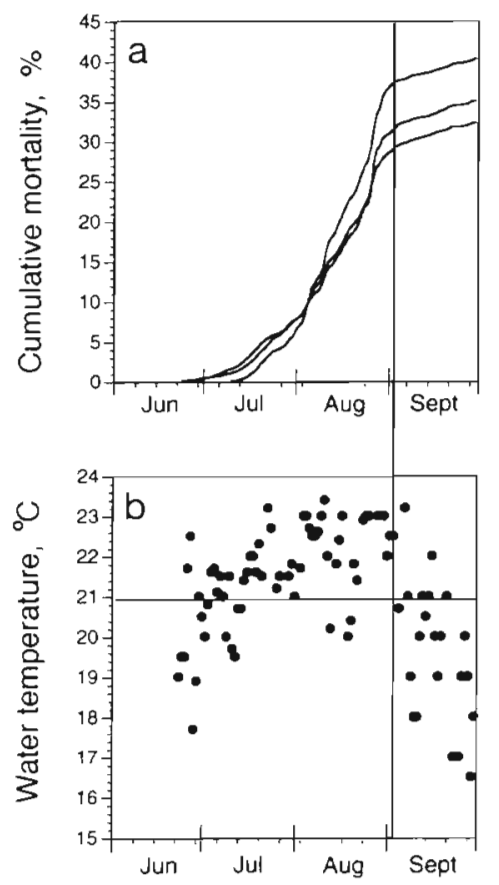

Fig. 1 Vibrio carchariae infecting Paralichthys dentatus. Cumulative mortality of summer flounder at the Quonset Point grow-out facility during the summer, 1998. (a) The 3 lines indicate mortality in 3 groups of juveniles (total $=21775$ ) that were raised in separate raceways. (b) Water temperature at the facility during the epizootic. The vertical reference line indicates the date at which the rate of mortality started to decline. The horizontal reference line indicates water temperature of $21^{\circ} \mathrm{C}$ from the anus and protruded from the anal area. One fish taken from a group of 6 healthy-looking fish that were sampled from the same tank as the diseased fish had a posterior intestine which was detached from the anus but which had healed forming a blind-sac, indicating that it may be a survivor of the disease (Fig. 2b).

Histopathological examination revealed that severe lesions were restricted mostly to the peritoneum and the posterior intestine (Fig. 2c,d). Large amounts of bacteria were observed in the peritoneum and at the serosal surface of the posterior intestine, associated with necrosis, fibrin deposition, haemorrhage, and inflammatory cell infiltration, consisting predominantly of lymphocytes and granulocytes (Fig. 2c,d). Damage was so severe in some fish that it caused the rupture of the intestinal wall. Bacterial colonies were also observed in the capsule of the spleen, perisplenic areas (perisplenitis, Fig. 2e) and in intrasplenic perivascular regions (Fig. 2f). Most spleens from diseased fish showed vascular congestion. No major lesions were observed in other tissues, although bacteria could be observed and isolated from the kidney.

\section{Isolation and characterization of the pathogen}

\section{Exclusion of viral or toxin origin}

Fish injected with unfiltered ascites fluid collected from diseased fish suffered $67 \%$ mortality (4 fish out of $6)$, whereas fish injected with filtered $(0.2 \mu \mathrm{m}$ pore size) ascites fluid or with NSS survived until they were sacrificed at the end of the experiment (at least 2 wk after injection). Since filtration through a $0.2 \mu \mathrm{m}$ pore size filter appeared to remove the agent of mortality, viruses and toxins were ruled out as the causative agents of FINE. Mortality was observed as soon as $1.5 \mathrm{~d}$ after injection and all deaths occurred within $3 \mathrm{~d}$ of injection. The dead fish showed the same clinical and histopathological signs observed in moribund fish from the grow-out facility. Their abdomens were distended from fluid collection in the peritoneal cavity, the peritoneal fluid was filled with serosanguineous fluid, there was redness around the anus, and 2 of the 4 dead fish had a prolapsed intestine. Histological examination revealed bacterial colonies on the serosal surface of the posterior intestine, associated with necrosis and inflammatory cell infiltration, consistent of mostly lymphocytes and granulocytes.

\section{Isolation of possible causative agent}

Five bacterial isolates (1 coccus and 4 rod-shaped bacteria) were obtained from moribund fish ascites 

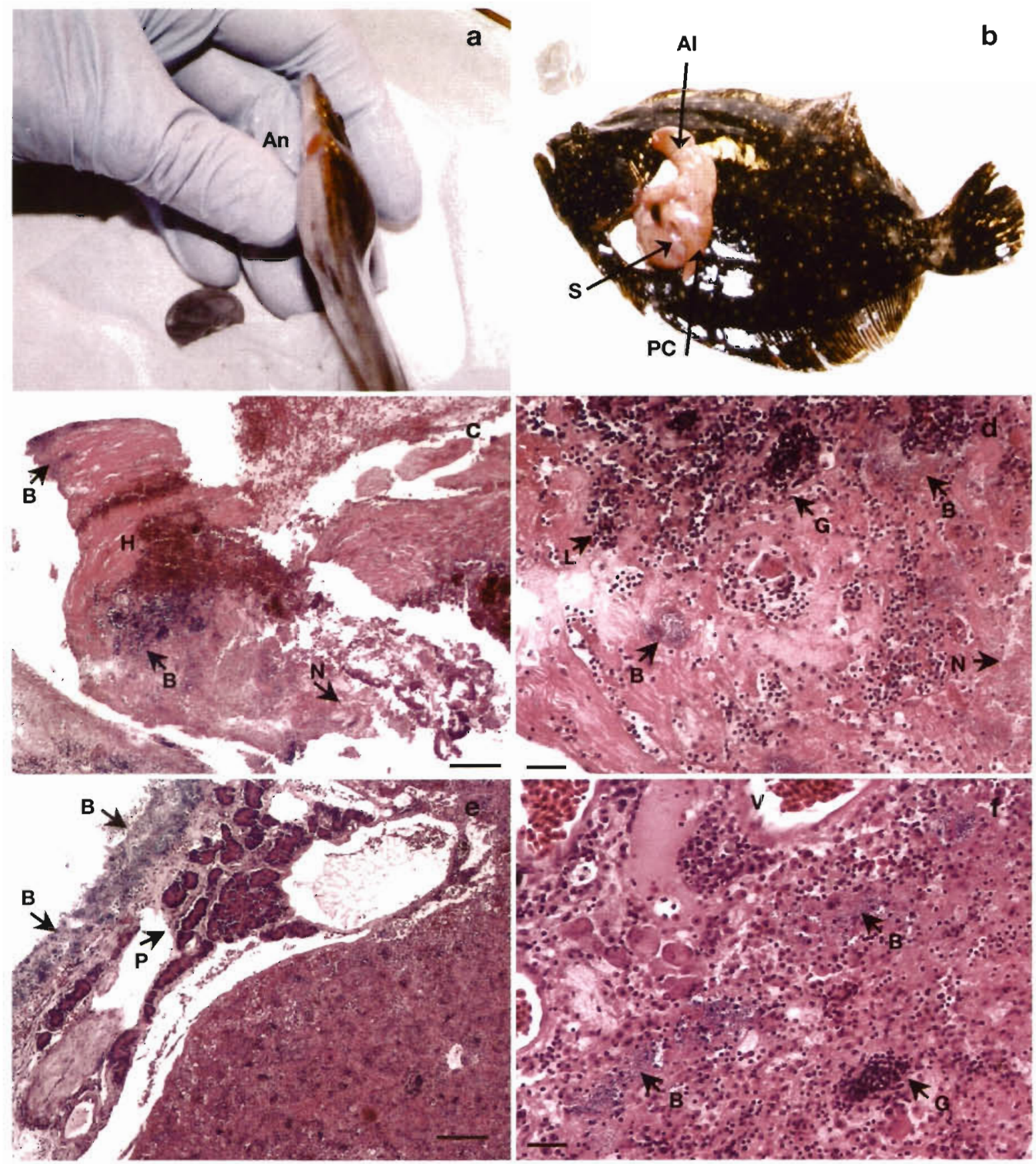

Fig. 2. Vibrio carchariae infecting Paralichthys dentatus. Gross and microscopic signs of FINE. (a) Juvenile summer flounder collected in late August, 1998, showing distended abdomen and red vent or anus (An). The abdominal cavity was filled with ascites fluid. (b) Juvenile summer flounder collected at the same time as the fish in Fig. 2a, showing a sealed intestine. The posterior intestine was missing and the anterior intestine (AI) and anal region (not visible) were truncated. S: stomach; PC: caecae. $(c, d)$ Lesions in the posterior intestine of summer flounder include necrosis $(\mathrm{N})$, hemorrhage $(\mathrm{H})$, and presence of inflammatory cells, mostly lymphocytes (L) and granulocytes (G). Bacteria (B) can be observed (in blue) in the intestinal wall. (e,f) Bacteria (B) can be observed in the serosal and capsular surface of pancreas and spleen and in areas close to mesenteric blood vessels (V). Pancreatic acinae (P) were not involved. H\&E. Scale bar $=100 \mu \mathrm{m}$ in (c) and (e), $20 \mu \mathrm{m}$ in (d) and (f)

fluid streaked onto blood agar plates. No bacteria could be isolated from the peritoneal cavity or kidneys of healthy-looking fish. Each isolate was grown sepa- rately and inoculated into fish to determine whether that organism was the causative agent of FINE. Fish inoculated with Isolates 2 and 4 produced the same 
gross and histological lesions as described in fish from the grow-out facility, including mortality within $3 \mathrm{~d}$ of injection. Isolate 2 killed 4 out of 5 fish, while Isolate 4 killed 3 out of 5 fish. The 2 isolates were considered to be the possible agents of FINE and were saved for further study. Isolates 1, 3, and 5 failed to produce any disease signs or mortality when injected into the fish and thus were excluded as possible causative agents of this disease outbreak. These isolates were not identified.

\section{Identification of the pathogen as Vibrio carchariae}

The 2 pathogenic isolates were identical in microscopic and colony appearance. The cells were Gramnegative motile rods. Colonies were smooth and sometimes exhibited swarming behavior after $24 \mathrm{~h}$ on LB20 agar. When grown on blood agar plates, each isolate exhibited $\beta$-haemolysis after 3 to $4 \mathrm{~d}$ of incubation.

Table 1. Biochemical characteristics of pathogenic Isolates 2 and 4 . NA: not available; V: variable result

\begin{tabular}{|c|c|c|c|}
\hline \multirow{2}{*}{$\begin{array}{l}\text { Biochemical test or } \\
\text { characteristic }\end{array}$} & \multicolumn{2}{|c|}{ Vibrio carchariae } & \multirow{2}{*}{$\begin{array}{l}\text { Isolates } \\
2 \text { and } 4\end{array}$} \\
\hline & $\begin{array}{l}\text { Austin \& Austin } \\
\qquad(1993)\end{array}$ & $\begin{array}{c}\text { Yii et al. (1997) } \\
(1997)\end{array}$ & \\
\hline$\beta$-galactosidase & - & V & - \\
\hline Arginine dihydrolase & - & - & - \\
\hline Lysine decarboxylase & + & + & + \\
\hline Ornithine decarboxylase & + & V & + \\
\hline Citrate & - & + & + \\
\hline $\mathrm{H}_{2} \mathrm{~S}$ production & - & $\mathrm{V}$ & - \\
\hline Urease & + & V & + \\
\hline Tryptophane deaminase & - & - & - \\
\hline Indole formation & + & + & + \\
\hline Acetoin production (VP) & - & V & - \\
\hline Gelatin liquefaction & + & $\mathrm{V}$ & + \\
\hline Glucose & + & + & + \\
\hline Mannitol & + & + & + \\
\hline Inositol & - & - & - \\
\hline Sorbitol & - & - & + \\
\hline Rhamnose & - & - & - \\
\hline Sucrose & + & + & + \\
\hline Mielibiose & - & - & - \\
\hline Amygdalin & - & + & + \\
\hline Arabinose & - & - & - \\
\hline Oxidase & + & NA & + \\
\hline Nitrite reduction & - & - & + \\
\hline Motility & + & + & + \\
\hline \multicolumn{4}{|l|}{ Growth on: } \\
\hline McConkey's agar & NA & + & + \\
\hline TCBS agar & NA & + , yellow & + yellow \\
\hline \multicolumn{4}{|l|}{ Antibiotic inhibition: } \\
\hline $0 / 129\left(20 \mu \mathrm{g} \mathrm{disk}{ }^{-1}\right)$ & NA & + & + \\
\hline Ampicillin $\left(100 \mu \mathrm{g} \mathrm{ml}^{-1}\right)$ & NA & - & - \\
\hline Tetracycline $\left(10 \mu \mathrm{g} \mathrm{ml}^{-1}\right)$ & NA & + & + \\
\hline
\end{tabular}

Each isolate gave identical biochemical test results on API 20E; the 2 isolates represent the same organism isolated from different fish (Table 1, identification profile number 4356525-77). Comparison of the test results with published API 20E profile identifications (API 20E Analytical Profile Index 1997. BioMérieux SA) showed strong similarities between our 2 isolates and either Vibrio parahaemolyticus or Vibrio alginolyticus. Comparison with the API $20 \mathrm{E}$ profiles of fish pathogens published by Austin \& Austin (1993), however, showed that the profile with the strongest similarity to our isolates was Vibrio carchariae. Our isolates differed only in 3 characteristics from the profile by Austin \& Austin (1993), being positive for citrate, amygdalin, and sorbitol utilization. Furthermore, the API $20 \mathrm{E}$ profile matched the profile observed by Yii et al. (1997) for $V$. carchariae isolated from an epizootic among grouper Epinephelus coioides in Taiwan (Table 1).

Additionally, data presented in Table 2 demonstrate that the required $\mathrm{NaCl}$ concentrations and temperatures for growth of our isolates closely matched those reported by Grimes at al. (1984) and Yii et al. (1997). Finally, our 2 isolates were sensitive to $0 / 129$ and tetracycline and resistant to ampicillin, as reported by Yii et al. (1997) for Vibrio carchariae. Thus biochemical profiles and growth characteristics

Table 2. Effect of $\mathrm{NaCl}$ concentration and temperature upon the growth of Isolates 2 and 4

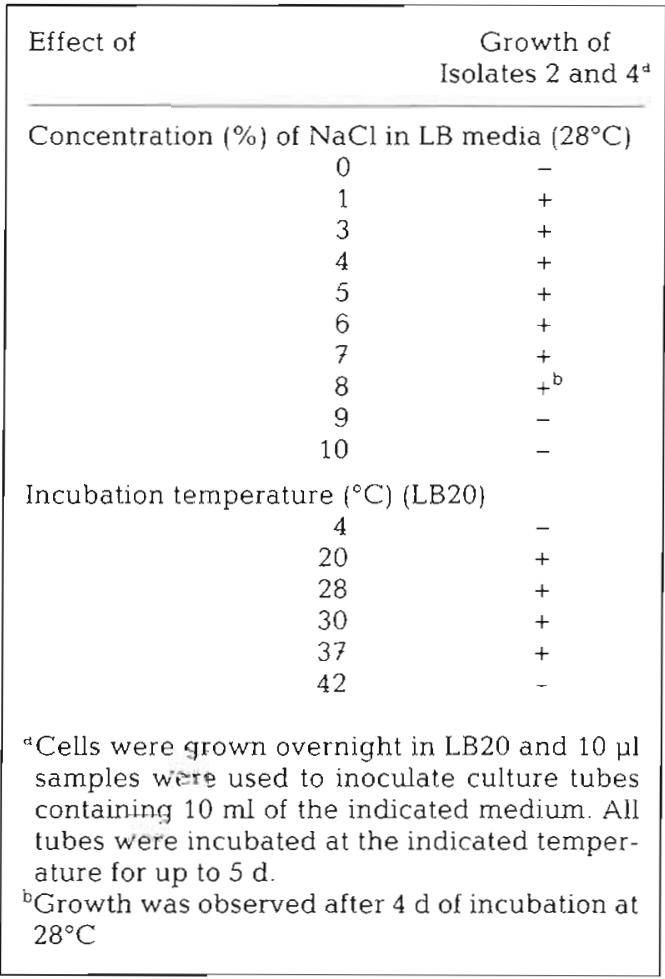


strongly support the identification of the causative agent of FINE as $V$. carchariae.

\section{Molecular confirmation of identity of pathogen}

To corroborate our identification of the pathogen as Vibrio carchariae, we sought to compare the DNA sequence encoding $16 \mathrm{~S}$ rRNA of our isolate with sequences in the genetic databases. The sequence of our isolate was $>99 \%$ identical to the published sequence of $V$. carchariae, and $98 \%$ similar to the next high scoring sequences (corresponding among others to $V$. harveyi, $V$. parahaemolyticus and $V$. alginolyticus). There was only 1 base pair difference (for a total sequence length of 1374 base pairs) between the flounder isolate and the reference $V$. carchariae 16S rRNA sequences (an adenine in position 980 of the published ATCC sequence is substituted for a cytosine in the flounder isolate), while there were 8 nucleotide differences from $V$. harveyi and 12 to 16 nucleotide differences from $V$. parahaemolyticus and $V$. alginolyticus (Ruimy et al. 1994) (not shown). The phylogenetic tree constructed confirmed the close relationship of $V$, carchariae isolates from flounder and shark (Fig. 3). These results confirm the identity of the flounder isolate as V. carchariae.

\section{Virulence}

The $\mathrm{LD}_{50}$ determination of Vibrio carchariae was conducted for $2 \mathrm{wk}$ and all deaths occurred within $3 \mathrm{~d}$. Based on the 2 experiments, the $\mathrm{LD}_{50}$ estimate was $5 \times$ $10^{5} \mathrm{cfu}$ fish $^{-1}$ (100 to $200 \mathrm{~g}$ body weight) (Fig. 4). V. carchariae was isolated from the dead fish and identified as the causative agent of FINE.
Status of surviving flounder following the epizootic

In order to determine the effect of the disease on the surviving population of summer flounder, random fish from the grow-out raceways were examined $2 \frac{1}{2}$ mo following the start of the epizootic and 1 mo after mortalities declined. In a portion of survivors of the epizootic, the posterior intestine was missing and there was no connection between the anterior intestine and the anus. The proportion of the fish without a posterior intestine was $14.8 \pm 9.5 \%$ (mean and $95 \%$ confidence interval). Of the 7 fish identified as missing the connection between the anterior intestine and the anus, 1 was infected and its posterior intestine was necrotic. In the other 6 fish, the severed intestines had healed on the remaining ends forming a blind-sac (similarly to fish shown in Fig. 2b). The anterior intestine healed and sealed between 1.5 and $2.5 \mathrm{~cm}$ past the pyloric caecae. Three of the intestine-sealed and otherwise healthy appearing fish contained feed in their gut. One of these fish was seen regurgitating the day previous to the sampling. The flounder with sealed intestines weighed less $(31 \pm 5 \mathrm{~g}$ vs $58 \pm 4 \mathrm{~g}, t$-test $\mathrm{p}<0.01)$ and were shorter $(14.2 \pm 1.0 \mathrm{~cm}$ vs $16.9 \pm 0.3 \mathrm{~cm}$, $t$-test $p<$ 0.01 ) than healthy looking summer flounder from the

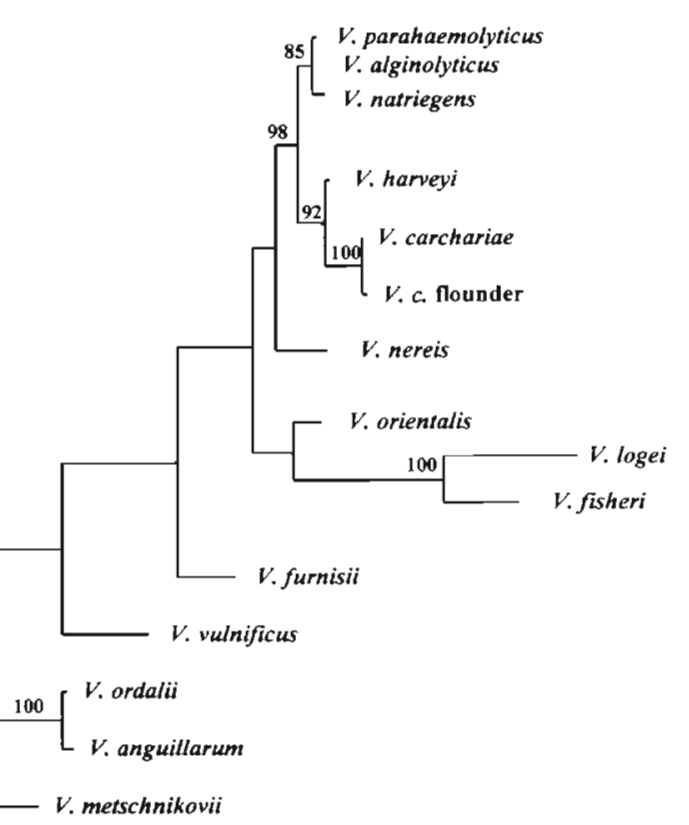

Fig. 3. Parsimony tree based on $16 \mathrm{~S}$ rRNA sequences showing the phylogenetic relationships among the Vibrio isolated from flounder (named $V$. c. flounder here) and other Vibrio species (see 'Materials and methods'). The numbers above the bar at each node are the percentages of bootstrap replications (only values above $50 \%$ are shown) 


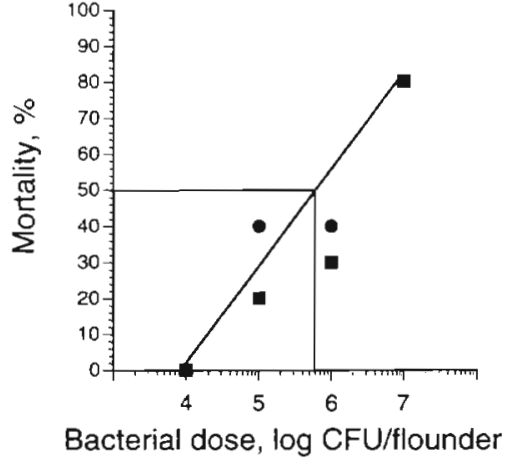

Fig. 4. Vibrio carchariae infecting Paralichthys dentatus. Cumulative mortality in summer flounder $\left(n=6\right.$ group $\left.^{-1}\right)$ at increasing doses of $V$. carchariae. $L_{50}$ was estimated by probit analysis to be $5 \times 10^{5} \mathrm{cfu} \mathrm{fish}^{-1}$ (100 to $200 \mathrm{~g}$ body weight). Exposure was by intraperitoneal injection. The experiment was duplicated ( $\bullet$ and $\bullet$ ). Duplicate experiments gave identical percent mortality at the highest and the lowest doses

same raceway (Fig. 5). The weight-length relationship was similar for fish with sealed and intact intestines.

\section{DISCUSSION}

The first epizootic of FINE in summer flounder Paralichthys dentatus in a grow-out facility in the East Coast of the USA is described. The identification of Vibrio carchariae as the causative agent of FINE is based on the consistent isolation of this bacterium from ascites and kidneys of diseased fish; challenge experiments that revealed the $V$. carchariae isolates caused disease and mortality in fish consistent with the signs observed in the grow-out facility; and biochemical, morphological, and molecular characteristics of the isolates that were identical with those characteristic for V. carchariae.

Vibrio carchariae was originally isolated from sharks (Grimes et al. 1984) and has subsequently been isolated from skin lesions in laboratory reared Octopus bimaculoides and $O$. maya and eye lesions in captive squid Sepioteuthis lessoniana (Hanlon \& Forsythe 1990). V. carchariae has also been shown to be responsible for gastroenteritis in grouper Epinephelus coioides (Yii et al. 1997). The clinical signs observed in summer flounder infected with $V$. carchariae are similar to those observed in grouper. These signs include a prominently distended abdomen, reddening around the anus, and presence of serosanguineous fluid in the peritoneum. Moreover, as in the grouper epizootic, mortalities in summer flounder caused by $V$. carchariae occurred during the summer, when water temperature exceeded $21^{\circ} \mathrm{C}$. Our isolate, however, seems to be more virulent in summer flounder than the Taiwan iso-

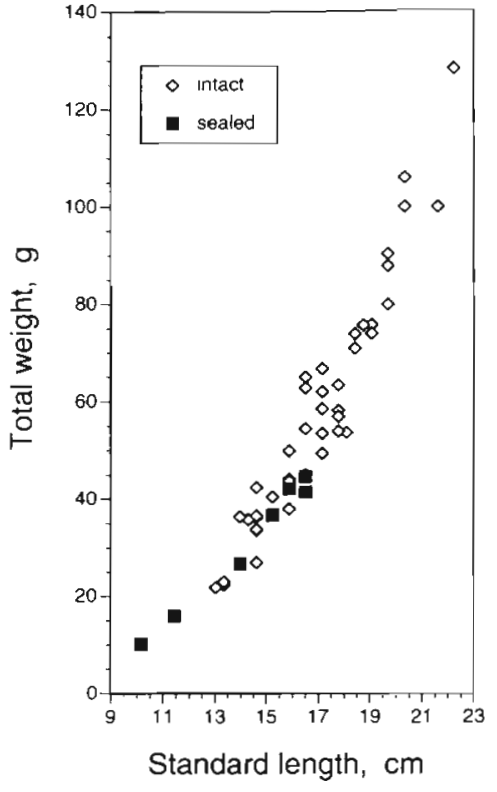

Fig. 5. Paralichthys dentatus. Comparison of the body weights and standard lengths of summer flounder with intact $(\diamond)$ and sealed ( $\mathbf{(})$ intestines. Fish were sampled on October 1, 1998. The proportion of summer flounder with sealed intestines was $15 \%$

late in grouper. The $\mathrm{LD}_{50}$ of the Rhode Island isolate in summer flounder is much lower than the $\mathrm{LD}_{50}$ of the Taiwan isolate in grouper $\left(5 \times 10^{3} \mathrm{cfu} \mathrm{g}^{-1}\right.$ summer flounder body weight compared to $2.5 \times 10^{7} \mathrm{cfu} \mathrm{g}^{-1}$ grouper body weight). Since few fish with similar clinical signs have been observed in the hatchery where fish came from (where temperatures are kept below $21^{\circ} \mathrm{C}$ ), we suggest that triggering factors for this epizootic are a combination of the stress induced by transportation combined with temperatures above $21^{\circ} \mathrm{C}$.

Vibrio carchariae resembles and is closely related to 3 other fish pathogens, V. harveyi, V. parahaemolyticus and $V$. alginolyticus. These organisms, however, are differentiated from $V$. carchariae on the basis of urease production. $V$. carchariae is urease positive, while the other 3 organisms are negative. While $16 \mathrm{~S}$ rRNA sequence analysis reveals that while all 3 Vibrio species are closely related, only the published sequence for $V$. carchariae 16S rRNA (Ruimy et al. 1994) shows almost full sequence identity to that of our isolate.

Intestinal infections associated with enteritis have been also observed in cultured larval Japanese flounder (Muroga et al. 1990) and summer flounder (Richard Wolke, University of Rhode Island, USA, pers. comm.). The causative agent for the larval enteritis in Japanese flounder, however, was identified as Vibrio ichthyoenteri, a new species of Vibrio. $V$. ichthyoenteri differs 
from $V$. carchariae in several biochemical characteristics, including chitinase, gelatinase and lipase activities (Ishimaru et al. 1996). Furthermore, the levels of relatedness at the DNA level (calculated as \% of DNA reassociation) between these 2 Vibrio species are lower than $15 \%$ (Ishimaru et al. 1996).

Although general similarities exist, the lesions caused by Vibrio carchariae are peculiar when compared to the lesions caused by other Vibrio species in adult flatfish. Histopathological damage seems to be restricted to the peritoneum and posterior intestine. Although the mode of infection is not known, it appears that the infection starts in the posterior intestine and then disseminates through the blood to other tissues. The posterior intestine and peritoneum may provide a microenvironment for the proliferation of the bacterium prior to dissemination and septicaemia. Preliminary observations show that when $V$. carchariae is grown in gastrointestinal mucus at $27^{\circ} \mathrm{C}$, the bacterium exhibits a generation time of $17 \mathrm{~min}$ (Gwaltney \& Nelson unpubl. obs.). This is a rapid growth rate and suggests that $V$. carchariae is well adapted as an intestinal pathogen. Similar observations have been made with regard to $V$. anguillarum. A major portal of entry for $V$. anguillarum is the gastrointestinal tract (Grisez et al. 1996, Olsson et al. 1996). Once inside the posterior colon and rectum, the invading bacteria grow explosively in the gastrointestinal mucus while expressing a variety of mucus-induced genes (Garcia et al. 1997, Denkin \& Nelson 1999).

FINE caused serious losses due to mortality at the grow-out facility. Furthermore, the disease could have a more covert but significant impact on flounder culture. A significant proportion of the survivors of the epizootic had no posterior intestine, but instead had a blind-sac made up of healed anterior intestine. Given the importance of drinking and of the role of the posterior intestine in salt and water balance in marine fishes (Smith 1932, e.g. Veillette et al. 1993), it is surprising that these fish were alive 1 mo after the epizootic subsided.

In summary, FINE is a bacterial disease identified in cultured summer flounder caused by Vibrio carchariae. Infections are capable of causing serious mortality in the intensive culture of juveniles. Whether it equally affects larvae or reproductive adults is not known. An economically deleterious, but physiologically intriguing aspect of the disease is that some fish recover and continue to feed even in the absence of a posterior intestine, but do not grow to full potential.

Acknowledgements. This work was supported by NOAA Office of Sea Grant, US Department of Commerce, under Grant No. NA36RG0503 awarded to M.G.-C., J.L.S., and D.R.N and by US Department of Agriculture NRICGP Grant
No. 97-35204-4811 awarded to D.R.N. We thank Greg and Valerie Huba, owners VG Seafarms LCC, for providing any and all information we needed to initiate and complete this work. Dr David Bengtson, University of Rhode Island (URI), is thanked for his expert advice and for his oversight of the Flounder Facility. We thank David Alves (URI) and Drs Carroll Jones (University of New Hampshire), Carlos MuroCacho (H. Lee Moffitt Cancer Research Center, Tampa, Florida), Roxanna Smolowitz (Marine Biological Laboratories) and Richard Wolke (URI) for helpful comments and sharing their knowledge on the biology and pathology of summer flounder. Steve Gavlik (URI) contributed importantly to the execution of the challenge experiments. The US Government is authorized to produce and distribute reprints for governmental purposes notwithstanding any copyright notation that may appear hereon.

\section{LITERATURE CITED}

Austin B, Austin DA (1993) Bacterial fish pathogens: disease in farmed and wild fish. Ellis Horwood, New York

Bengtson DA (1999) Aquaculture of summer flounder (Paralichthys dentatus): status of knowledge, current research, and future research priorities. Aquaculture 176 $39-49$

Burke JS, Miller JS, Hoss DE (1991) Immigration and settlement pattern of Paralichthys dentatus and P. lethostigma in an estuarine nursery ground, North Carolina, USA. Neth J Sea Res 27:393-405

Denkin SM, Nelson DR (1999) Induction of protease activity by gastrointestinal mucus in Vibrio anguillarum. Appl Environ Microbiol 65:3555-3560

Garcia T, Otto K, Kjelleberg S, Nelson DR (1997) Growth of Vibrio anguillarum in salmon intestinal mucus. Appl Environ Microbiol 63:1034-1039

Giovannoni SJ, Britschgi TB, Moyer CL, Field KG (1990) Genetic diversity in Sargasso Sea bacterioplankton Nature 345:60-63

Grimes DJ, Colwell RR, Stemmler J, Hada H, Maneval D. Hetrick FM, May EB, Jones RT, Stoskopf (1984) Vibrio species as agents of elasmobranch disease. Helgol Wiss Meeresunters 37:309-315

Grisez L, Chair M, Sorgeloos P, Ollevier F (1996) Mode of infection and spread of Vibrio anguillarum in turbot Scophthalmus maximus larvae after oral challenge through live feed. Dis Aquat Org 26:181-187

Hanlon RT, Forsythe JW (1990) Diseases of mollusca: Cephalopoda. In: Kinne O (ed) Diseases of marine mammals, Vol III. Introduction, Cephalopoda, Annelida, Crustacea, Chaetognatha, Echinodermata, Urochordata. Biologische Anstalt Helgoland, Hamburg, p 21-43

Higgins DG, Bleasby AJ, Fuchs R (1991) CLUSTAL V: improved software for multiple sequence alignment. CABIOS 8:189-191

Iida Y, Masumura K, Nakai T, Sorimachi M, Matsuda H (1989) A viral disease in larvae and juveniles of the Japanese flounder Paralichthys olivaceus. J Aquat Anim Health 1: $7-12$

Ishimaru K, Akagawa-Matsushita M, Muroga K (1996) Vibrio ichthyoenteri sp. nov., a pathogen of Japanese flounder (Paralichthys olivaceus) larvae. Int J Syst Bacteriol 46 155-159

Keefe M, Able KW (1993) Patterns of metamorphosis in summer flounder, Paralichthys dentatus. J Fish Biol 42 $713-728$

Lane DJ (1991) 16S/23S rRNA sequencing. In: Stackebrandt 
E, Goodfellow M (eds) Nucleic acid techniques in bacterial systematics. John Wiley \& Sons, Chichester, p 115-163

Levin MA, Wolke RE, Cabelli VJ (1972) Vibrio anguillarum as a cause of disease in winter flounder (Pseudopleuronectes americanus). Can J Microbiol 18:1585-1592

Lupiani B, Dopazo CP, Ledo A, Fouz B, Barja JL, Hetrick FM, Toranzo AE (1989) New syndrome of mixed bacterial and viral etiology in cultured turbot Scophthalmus maximus. J Aquat Anim Health 1:197-204

Marden PA, Tunlid AK, Malmcrona-Friberg KG, Odham G, Kjelleberg S (1985) Physiological and morphological changes during short term starvation of marine bacteriological isolates. Arch Microbiol 142:326-332

Muroga K, Yasunobu H, Okada N, Masumura K (1990) Bacterial enteritis of cultured flounder Paralichthys olivaceous larvae. Dis Aquat Org 9:121-125

Neidhardt FC, Bloch PL, Smith DF (1974) Culture medium for enterobacteria. J Bacteriol 119:736-747

Nelson DR, Sadlowski Y, Eguchi M, Kjelleberg S (1997) The starvation-stress response of Vibrio (Listonella) anguillarum. Microbiol 143:2305-2312

Nguyen HD, Mekuchi $T$, Imura $K$, Nakai $T$, Nishizawa $T$, Muroga K (1994) Occurrence of Viral Nervous Necrosis (VNN) in hatchery-reared juvenile Japanese flounder Paralichthys olivaceus. Fish Sci 60:551-554

Editorial responsibility: David Bruno,

Aberdeen, Scotland, UK
NOAA/NMFS (1993) Fisheries of the US. US Department of Commerce, Silver Spring, MD

Olsson JC, Jöborn A, Westerdahl A, Blomberg L, Kjelleberg S, Conway PL (1996) Is the turbot, Scophthalmus maximus (L.), intestine a portal of entry for the fish pathogen Vibrio anguillarum? J Fish Dis 19:225-234

Ruimy R, Breittmayer V, Elbaze P, Lafay B, Boussemart $O$ Gauthier M, Christen R (1994) Phylogenetic analysis and assessment of the genera Vibrio, Photobacterium, Aeromonas, and Plesiomonas deduced from small-subunit rRNA sequences. Int J Syst Bacteriol 44:416-426

Smith HW (1932) Water regulation and its evolution in the fishes. Q Rev Biol 7:1-26

Stoskopf MK (1993) Fish medicine. WB Saunders Company, Philadelphia, PA

Veillette PA, White RJ, Specker JL (1993) Changes in intestinal fluid transport in Atlantic salmon (Salmo salar L.) during parr-smolt transformation. Fish Physiol Biochem 12: 193-202

Wiklund T, Dalsgaard I (1998) Occurrence and significance of atypical.Aeromonas salmonicida in non-salmonid and salmonid fish species: a review. Dis Aquat Org 32:49-69

Yii KC, Yang TI, Lee KK (1997) Isolation and characterization of Vibrio carchariae, a causative agent of gastroenteritis in the groupers, Epinephelus coioides. Curr Microbiol 35:109-115

Submitted: May 7, 1999; Accepted: September 7, 1999

Proofs received from author(s): November 9, 1999 